\title{
Klasik Dönem İslam Düşüncesinde Dünya Merkezli Evren Algısı ve Teolojik Nedenleri*
}

\section{World-Centered Perception of the Universe in Classical Period Islamic Thought and Its Theological Reasons}

Ertuğrul Cesur a,*

${ }^{a}$ Dr. Öğr. Üyesi, Muş Alparslan Üniversitesi, İslami İlimler Fakültesi, Mezhepler Tarihi ABD, 49250 Muş/Türkiye. ORCID: 0000-0003-3915-8780

\section{MAKALE BİLGISI}

\section{Makale Geçmişi}

Başvuru tarihi: 30 Mart 2021

Düzeltme tarihi: 01 Temmuz 2021

Kabul tarihi: 10 Temmuz 2021

\section{Anahtar Kelimeler:}

Astronomi

Rasathane

Dünya Merkezli

Kopernik

Zillullah

\section{A R T I C LE INFO}

\section{Article history:}

Received: 30 March 2021

Received in revised form: 01 July 2021

Accepted: 10 July 2021

\section{Keywords: \\ Astronomy \\ Observatory \\ Earth-Centered \\ Copernicus \\ Zillullah}

ÖZ

Klasik tefsir kitaplarına yansıdığı üzere Müslüman düşüncesinde de hâkim evren resmi aslında Antik Çă̆'dan modern zamanlara, dünyanın hemen her yerinde geçerli geosantrik evren modelidir. Nihayetinde Kur'an'ın asli gayesi astronomi bilgisi değil, geçerli dış dünya algısı ne olursa olsun insanların yeryüzünü ifsat etmeden bir arada yaşayabilecekleri bir toplum düzeni yönünde yaratılış gayesine matuf ilkeleri hatırlatmaktır. Bunu yaparken de dönemin dil ve kültürel gerçeklerinden hareket eder. Buna göre verili kültürün kendi iç tutarlılığ içinde bu hikmeti gözeten bir toplumsal düzen tesis edilen ilk İslam toplumda siyasal sistemin dayanağ 1 tanrısal temsil de "halife" kavramı üzerinden topluma şamil hale gelir. Ne var ki, Hz. Peygamber sonrası siyasi ihtilaflarda tarafların kendi konumlarını dini referanslarla tahkim etmeleri, dünya merkezli bir evren fikrine ilişkin teolojik kabulleri pekiştirir.

\section{A B S T R A C T}

The picture of the dominant universe in the Muslim World, as reflected in the classical literature, was not different from the geocentric idea of the universe. The purpose of the Quran is not to teach people astronomy lessons, but to establish a social order in which people can live together without spoiling the earth, regardless of the prevailing perception of the external world. According to this, "divine representation", which was the basis of the political system in the first Muslim society, is attributed to the society with the concept of "caliph". However, in the post-Prophet political conflicts, the parties' fortification of their positions with occultist references, reinforced the theological assumptions regarding the idea of an earth-centered universe.

\section{Giriş}

... Binlerce defa söylememe ră̆men üniversitenin önde gelen profesörleri bir kez olsun teleskoptan bakmaya bile yanaşmıyorlar. Burada olmanı çok isterdim. Böylece bunların hallerine bakıp birlikte kahkahalarla gülerdik.

GALILEO

(Kepler'e yazdığı mektup)
Modern tarih ve dil çalışmaları göstermiştir ki, milletlerin dilleri ne Yunan mitolojisindeki gibi Hermes vergisidir (Gera, 2003: 117), ne de Tevrat'ta anlatıldığ gibi Babil kulesinden saçılmıştır (Tekvin, 11/9). Diller, insanoğlunun dünya üzerindeki kadim varlığının, tecrübelerinin zihinsel hasılasından ibarettir. Yaratılışı gereği asli iletişimi "ses" ile gerçekleşen insanoğlu beş duyudan gelen verilerden oluşan

\footnotetext{
*Bu çalışma, 7 Aralık 2020 tarihinde Muş Alparslan Üniversitesi İslami İlimler Fakültesinde düzenlenen İslam Düşüncesinde Eleştiri Kültürü ve Tahammül Ahlâkı II (Klasik Dönem - M. VII. - XII. Yüzyıllar) Sempozyumunda sunulan bildirinin geliştirilmiş halidir.

** Sorumlu yazar/Corresponding author

e-posta: e.cesur@alparslan.edu.tr
} 
zihinsel üretimini ses kalıplarına döker ve sözcükler meydana gelir. Sözcükler yoluyla anlamlandırdiğ $\iota$ dış dünyanın soyut - zihinsel bir modelini inşa eder. Buna göre kurduğumuz her cümle aslında zımnen bir dünya modeli (mekân algıs1) içerisinden dile gelmekte olup her bir sözcük tercihi zihin dünyasına açılmış küçük bir pencere şeklinde kişinin dünya görüşü hakkında fikir verir. Haliyle beş duyunun pek az ötesine geçen eski zamanların dünya modelinde aslında "dünya" dendiğinde de modern insanın zihnimizdekinden tümüyle farklı bir imaj oluşmaktadır. $\mathrm{Bu}$ durum kendisini dil üzerinden dini metinlerde de göstermiş ve kalıcılaşmıştır. $\mathrm{Bu}$ metinlere bakıldığında kadim zamanlardan Orta Çă̆'ın sonlarına kadar -birbirinden habersiz dahi olsa- dünyanın hemen her yerinde insan topluluklarının en üst mekân algısı olarak Dünya Merkezli (Geosantrik) bir evren modeline (kozmoloji) vardığ görülmektedir (J. Tassoul ve M. Tassoul, 2004: 9).

$\mathrm{Bu}$ kozmoloji, dini metinler üzerinden teolojinin de konusu haline gelir. Bu teolojiye göre Antik Çağ'dan Orta Çă̆'ın sonuna kadar dünyanın hemen her yerinde hükümdar, "en üst gök katmanında" olduğu düşünülen tanrı (ya da tanrıların) yeryüzündeki temsilcisi, "gölgesi" konumundadır (Bastian, 1860: 2/413). Meşruiyeti göklerden gelen hükümdar "yazgı" mahiyetinde "seçilme" göstergesi olaylar sonucu bu hakkı doğuştan elde etmiş olur. Bu nedenle dünyanın dört bir yanında hanedanlar meşruiyetlerini pekiştirmek için kutsal şecerelerini yazdırırlar (Ortaylı, 2007: 171). Ancak Batı Roma'nın çöküşüyle (476) meydana gelen otorite boşluğunda Avrupa coğrafyası dünyanın geri kalanından farklı bir sürece girer. Roma ruh olarak ortadan kalkmış ise de ortada devasa bir "beden" (miras) kalmıştır ve bu mirası sahiplenme konusunda amansız bir rekabet yaşanacak, Rus hükümdarları dahi Roma'nın varisi anlamında "Çar" unvanını alacak (Akçura, 2016: 47), hatta Fatih Sultan Mehmet kendisini "Kayser-i Rum" ilan edecektir. Bu sahiplenmeye Kilise de katılır ve daha 5. yy.dan itibaren İsa'nın vekili olarak tanrının hakkını temsil etmenin yanı sıra -artık ortada bir Sezar olmadığına göre- Sezar'ın hakkının da kendisine devredildiği (Konstantin Bağışı) iddiasındadır (Ağaoğulları, 2020: 267). Bu durum zamanla Kilise ile Kutsal Roma Cermen İmparatorları ve krallar ve arasında yeni bir iktidar mücadelesine neden olur. "İki kılıç öğretisi" gibi teolojik argümanlar geliştiren papalar adeta yeni Roma imparatoru edasıyla yürür. Ancak 16. yy.a gelindiğinde Avrupa'da tüm "tanrısal vekâlet" sistemi ve evren algısının yıkılmasına neden olan yeni bir gelişme yaşanır: Kopernik Devrimi.

Kopernik (ö. 1543), Göksel Kürelerin Devinimi Üzerine adlı eserinde, Aristarkus gibi Antik Çağ bilginleri tarafindan dillendirilen ancak o zamana kadar hemen hiç itibar edilmeyen Güneş merkezli (Heliosentrik) evren modelini canlandırır (J. Tassoul ve M. Tassoul, 20). Bu durum, Kilise ve Saray arasındaki çekişmeye konu olan koltuğun, her iki taraf açısından da altlarından çekilmesi anlamına gelmektedir. Artık insanoğlunun dış dünya algısını tümüyle değiştirmenin; yeni bir evren modeline geçmenin zamanı gelmiştir. Bu durum tüm diğer tarihlendirmelerden çok daha fazla Kopernik Devrimini bilimsel devrimin başlangıcı kılar (Cohen, 1994: 68). Bunun sessiz bir geçiş olmayacağının gayet farkında olan Kopernik de kitabını ancak ölümüne yakın bir tarihte yayınlatır. Kopenik'in ardından Galileo ve Kepler gibi başka bilginler de dünya yerine Güneş merkezli evren fikrini dillendirince 16. ve 17. yy.larda Avrupa büyük bir astronomi tartışmasına sahne olur. $\mathrm{Bu}$ bilginlerden Danimarkalı gök bilimci Tycho Brahe (ö. 1601), Kral II. Frederick'i ikna ederek 1576'da Hven adasında Yeni Çă̆'ın ilk rasathanesini kurar (Akgül, 1997: 35). Brahe'in çalışmaları günümüz Güneş sistemi modeli için önemli bir adım olacaktır.

Evren fikrindeki değişimin hikâyesi bugün Avrupa dış1 toplumlarda bile hala başta Galileo'nun başına gelenler üzerinden bir darbı mesel olarak dilden dile dolaşır. İlginçtir ki, hafızalar yoklandığında aynı Dünya Merkezli evren fikrine sahip Müslümanların dünyasında böylesi bir tartışma görülmez. Müslümanlar, belirsiz bir tarihten itibaren istemeyerek de olsa Batı'da gelişen bilimsel bilgiye uyum sağlamaya başlamışlar, ancak bunun bir dünya görüşü sorunu olarak neden olması gereken tartışmalar hemen hiçbir zaman gerçekleşmemiştir. Yaşanan sürecin felsefi temellerini görmeden sadece sonuçlara muhatap olmanın neticesi bir modernleşme çabası, muhafazakâr odaklarda uzlaşmaz bir mukavemetle karşılaşır (bkz. İpşirli - Çelebi, 2007: XVI/321). Değişimin bir türlü içselleştirilememesi, modernleşmenin tek mümkün yolunun "Batılılaşma" olduğu yönünde kanaatleri pekiştirir. Bu durumu daha da içinden çıkılmaz hale getiren, Batı sömürgeciliğinin özellikle İslam dünyasındaki agresif tutuculuğu besleyen provokasyon ve ajitasyon programıdır. İslam dünyası modernlik sorununu henüz tartışmaya başlamışken aslında Batıda çoktan postmodern program yürürlüğe konmuştur (Toynbee, 1987: 39). Bu programla, kökleri İslam tarihinde de yıkıcı sonuçları olmuş ancak zaman içinde nispeten baskılanmış akımların palazlanmasına imkân verilir (bkz. Vural, 2006: 37). Böylece Hindistan'dan Kuzey Afrika'ya özellikle İngiliz sömürgeciliğinin himayesinde Vahhabilik ve benzeri selefi akımlar kol budak sararken Batı karşısındaki zayıflık sorununun çözümüne en ufak bir katkı sağlamayan ama siyaset kurumunun tüm girişimlerini "gâvurlaşma” olarak karalayan bir söylem baş gösterir (Sultanefendi, 2002: 1/37).

Oysa modernite, görünen yüzünden çok öte büyük felsefi sonuçları olan insanoğlunun "dış dünyaya" (evren) ilişkin algısındaki bir değişimi (paradigma değişikliği) ifade eder (Kuhn, 1995: 98). Bu değişimi anlayabilmek ise "mekân" algısının felsefi düşünce açısından öneminin farkındalığını gerektirir. İnsani düşüncenin kuşatıcı, değer merkezli "evrensel" ifadesi olan felsefe ancak aktüel zamanın en kapsayıcı mekân fikrine dayanarak mümkün olur. Buna göre kozmoloji, mekân algısının felsefeye aktarılışı, bir evren modeline dönüşmesidir. İnsanoğlunun varoluş felsefesi ve birlikte yaşama (siyaset) kuramları da bu zeminde yükselir. Ne var ki kozmolojideki değişimin görmezden gelinmesi bizi yaklaşık beş asırdır aktüel çağın yabancısı bir hayata mecbur etmiştir. Dünya çapındaki büyük gelişmeler bu değişimi görmeden Müslüman kalarak sonraki çağlara geçmenin de mümkün olmayacağını göstermektedir. Müslümanların iddialarını sürdürebilmeleri, İslam'ın kendi iç dinamiklerinden bu paradigma değişiminin felsefi temellerine inilmesine, İslam'in ahlak ve siyaset felsefesini bu temel üzerine yeniden inşasına bağlıdır.

\section{1. İslam Öncesi Arabistan Yarımadası ve Düalist Evren Tasavvuru}

Klasik tefsir kitaplarına da yansıdığı üzere Kur'an'daki evren resmi aslında Antik Çağ'dan Orta Çağ'a uzanan verili geosantrik evren fikrinden farklı değildir. Nihayetinde 
Kur'an'ın bir bilim - astronomi kitabı ya da bu yönde bir iddiası olmadığına göre bunda şaşılacak bir durum da yoktur. Kur'an'ın asıl gayesi -içinde bulunulan çağda -kültürel seviye ne olursa olsun- insanların yeryüzünü ifsat etmeden, kan dökmeden (el-Bakara, 2/30) bir arada yaşayabilecekleri bir toplum düzenini tesis etmeleri yönünde yaratılış gayesine matuf ilkeleri hatırlatmaktır. Ancak Bunu yaparken de dönemin dil ve kültürel gerçeklerini baz alarak hareket edilmesi mantıksal bir zorunluluktur (Dönmez, 2007: XXXIV/127). Bunun verili duruma teslim olmak anlamına gelmediği açıktır. Aksine; asli gayeye (hikmet) ulaşmak için "eldeki malzemenin" bilinmesi elzemdir. Buna göre İslam, içinde doğduğu toplumun (ve dönemin) evren algısını dikkate almış ancak burada son derece esaslı değişikliklere gitmiştir. Hatta Kur'an'ın özü ve Hz. Peygamber'in gerçekleştirdiği toplumsal değişimin anlaşılması da İslam öncesi Arap toplumunun felsefi, siyasi ve sosyal gerçekliğinin anlaşılmasına bağlıdır.

İslam'ın ortaya çıktığı zamanlarda askeri ve iktisadi olarak Sasani nüfuzu görülen Arabistan yarımadası (bkz. E. Bağdâdî, 2009: 266) inanç dünyası açısından da iyicil (rahmani) ve kötücül (şeytana da tanrısallık atfeden) düalist bir kozmolojiye dayanan Mecusilik etki altındadır. Bu durum, İslam'ın doğuş yıllarında yaşanan Sasani - Doğu Roma savaşında müşriklerin, Sasanilerin zaferinden (618) sevinç duymaları şeklinde Kur'an'a yansır (er-Rum 30/2-5). Sasanilerin Doğu Roma karşısındaki zaferi, Cahiliye Araplarının da inanç dünyasını teşkil eden ve Allah karşısında şeytana da tanrısallık atfeden düalizmin, (Hz. İsa'nın zatı ve Allah'ın sıfatları üzerinden ihtilaflarla tevhidin bozuk bir yorumu olarak görebileceğimiz) teslis karşısındaki başarısıdır. Cahiliye dönemi düalist inanışa göre ruhlar âlemi, bir tarafta "Allah" ve ona itaatkâr melekler, diğer tarafta ise Allah'a "asi” iblis ve diğer şeytanlaşmış “cinler” şeklinde iki kutupludur (İbn Kesîr, 1999: VII/7) Bu iki kutup arasında çatışma yaşanmakta, insan da bu çatışma ortamında "arada kalmış" durumdadır. Bu nedenle müşrikler yolculuklarda özellikle kendilerini güvensiz hissettikleri ve şeytanların hâkim olduğunu düşündükleri mekânlarda oranın "şerir varlıklarının efendisine" sığınma şeklinde bir duada bulunurlar (Mahallî ve Süyûtî, 1971: 572). Zerreden küreye her şeye etki eden bu çatışma, insanoğlu için de kendi iradesinin ötesinde "zamanda yolculuğunu" belirleyen ve (çöl hayatı düşünüldüğünde) çoğunlukla da musibetler getiren bir sentez sonuca götürür. Müşrikler buna "zaman" anlaminda Dehr derler (Ciavuk, 1977: 193).

\section{Rahmani}

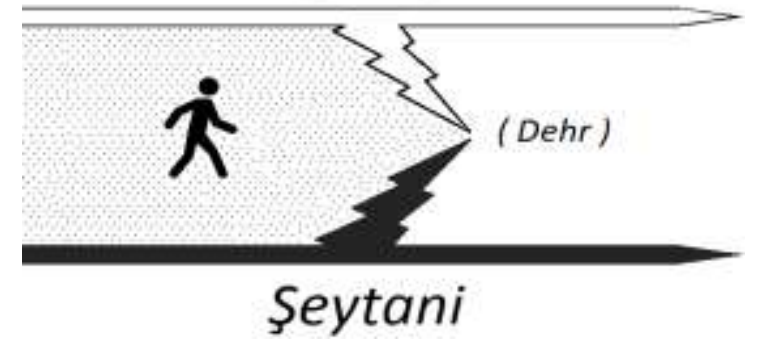

$\mathrm{Bu}$ düalist evrende müşrikler hem "rahmani" hem de "şeytani" güçleri neredeyse aynı düzeyde hayatlarına müdahil gördükleri için iki tarafı da memnun etmenin yollarını ararlar. Bunun için bir yandan "dişilik" atfederek
(ez-Zuhruf, 43/19) “Allah'ın kızları” (es-Saffat 37/149-152) olduğunu ileri sürdükleri melekler üzerinden Allah'a yaklaşmaya çalışırlar. Kâbe'nin etrafına dikilen temsiller (putlar) aslında melekler için dikilmiş sureta "bedenler" olup onlarla irtibat kurabilmek maksadiyla (insandaki ruh-beden ilişkisi gibi) meleklerin bu heykellerde temessül ettiklerine inanılır (Zeydan, 2013: III/23). Öte yandan 1ssiz ya da metruk yerleri, şeytanların mekânları görürler ve onlar için de oralarda sunaklar inşa ederler (İbnü'l-Kelbî, 1995: 20). Kimi gizil bilgileri bildiklerine inanılan kâhinlerin gerçekte, "yedinci gök katından" bu bilgileri çalıp onlara getiren "cinler" sayesinde bunlara vakıf oldukları düşünülmektedir (el-Cin 72/9).

\section{2. İslam'ın Getirdikleri}

İslam en başta cahiliyenin düalist kozmolojisini kesin bir dille reddeder. İslam ile birlikte göklerin kapıları kapatılmış, şeytanlar için ilahi âlemden gizil bilgileri dinleme imkânı kalmamıştır (Saffat 37/6-10). Şeytanlar gerçekte insanlara etki edebilecek bir güce de malik değildir (en-Nahl 66/9899). Doğada Allah'tan başka bir gücün etkisi ve belirleyiciliği olamaz. Buna göre insan - doğa ilişkisi rasyonel bir temelde yeniden tarif edilmiş olur. İnsanların başlarına gelen kötülüklerin (şer) nedenleri "şerir ruhlar" değil, insanların kendi elleriyle işlediklerinden dolayıdır (erRum 30/41); doğada "kötülük" yoktur.

Bu kozmoloji değişikliğinin toplumsal - siyasal sonuçları da vardır. Her şeyden önce meşruiyetini kötücül güçler konusundaki okültist yeteneklerinden alan kâhinlerin, şairlerin toplumsal nüfuzu kırılmıştır. Öte yandan $\mathrm{Hz}$. Peygamberle birlikte peygamberlik de sona erecek (hatm-i nübüvvet, Ahzab 33/40), Allah'ın bir insanı bu anlamda muhatap alması (teoloji) -kıyamete kadar- son bulacak, insanoğlu açılan çığırdan yolun bundan sonrasını kendisi yürüyecektir (sosyoloji). Bu çı̆̆ırı açan Hz. Peygamber'in bilindiği üzere Yesrib'e hicretinden sonra ilk yaptığı iş bir "yazılı belge" ile kentteki tüm unsurları bir arada yaşayabilecekleri ortak bir paydada buluşturmak olur. Son derece eşitlikçi adilane ilkelerden oluşan belgede bir ümmet tarifi de görülür. $\mathrm{Bu}$ tarifin sadece Müslümanları değil, belgeye imza koyan herkesi kapsadığı açıkça görülmektedir:

$$
\begin{aligned}
& \text { هذا كتاب من محمد النبي بين المؤمنين و المسلمين من قريش و أهل يثرب أنهاب }
\end{aligned}
$$

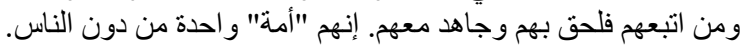

$\mathrm{Bu}$, Kureyşli Müminler ve Müslümanlar ile Yesribliler ve onlara tabi olanalar ve onlardan sayllanlar ve onlarla birlikte savaşanlar arasında Peygamber Muhammed (as) tarafından (yazdırılmış) vesikadır. Bunlar, diğer insanlardan ayrı tek bir "ümmet" teşkil ederler (İbn Hişam, II/143).

Bundan böyle Yesrib şehri bir "Medine" vasfı (Yesrib Medinesi) kazanmıştır. İşlerin "şura” ile yürütüldüğü Medine bir çeşit "cumhuriyet" anlamındadır. Hz. Peygamber' in bu pratiğinden hareketle ümmet kavramı için belli bir coğrafyayı yurt edinmiş, birbirlerinin hukukuna saygı çerçevesinde bir arada yaşama idealini yansıtan bir yazll belgeye imza koymuş, bu belgeyi iktisadi ve askeri olarak da koruyabilecek güce sahip topluluk olduğu söylenebilir. Öyle ki Medine'de yaşayan ve bu belgeye imza koyanlar ümmetten sayıldığı halde, Müslüman olup hala Hicret etmemiş olanlar ümmet mefhumunun dişında tutulmaktadır: "Iman edip de hicret etmeyenler ise hicret edinceye kadar onlarla sizin bir velayetiniz yoktur." (en- 
Enfâl 8/72) Tüm bunlar göz önünde bulundurulduğunda kavram günümüzde ulus/millet (nation) kavramına tekabül etmekte olup modern Arapçada da isabetli olarak ümmet kavramı "ulus" anlamında kullanılmaktadır (ör. الامم المتحدة Birleşmiş Milletler). Kavramın felsefi anlamına bakıldığında da çoğunlukla zannedilenin aksine bir "çokluk" değil; Kur'an'da ifade edildiği üzere "azlık" vurgusu vardır. İnsanlığın her türlü zorbalıktan uzak, herkesin hakkının güvence altına alındığı bir ideal toplum düzeni idealist insanları gerektirir. Toplumunda yalnız kalan $\mathrm{Hz}$. Ibrahim “tek başına ümmettir.” (en-Nahl 16/120) Kur'an, aslında her zaman azınlık olarak kalmaya mahkûm bu idealizmi ayakta tutmaya çağırır: "Sizden; hayra çă̆ıran, iyiliği telkin eden ve kötülükten sakındıran (az da olsa) bir topluluk (ümmet (أمة bulunsun” (Ali İmran, 3/104).

Ümmet tanımından anlaşılacağı üzere İslam'ın siyaset felsefesi, varlık şuuru son derece güçlü bireyleri gerektirir. Böylesi güçlü bir birey imgesine "akıl" vurgusunun eşlik etmesi tesadüfi değildir. Davranışlarını mensubu olduğu gruba endeksleyen kabile düzeninin aksine bireyler bilinçli tercih yapmaya çağırılır (el-Bakara 2/170). İslam'ın bu güçlü birey vurgusu Kur'an'ın insan felsefesini anlatan $\mathrm{Hz}$. Âdem' in yaratılış kıssasında çok daha belirgindir (el-Bakara 2/30). Yeryüzünde Allah adına tasarrufla görevlendirilen insan (Râfî̂, 1997: 13) toplumsal düzen için de yetkilendirilmiştir (Râfî̀, 18). Âdem'in şahsında “insan türü” (Zemahşerî, 1998: I/ 251) kast edilmiştir. Buna göre tüm insanlar için "Allah'ın halifesi” sıfatı geçerlidir (Râzî, 1938: II/165). Kur'an'da bu kavramın bir diğer kullanımı Davut Peygamber hakkındadır (es-Sad, 38/25). Buradaki ise liderin topluma vekâleti (hilafeti) anlamındadır. Kur'an'da yönetimle ilgili bir diğer esas da "şura" ilkesidir (eş-Şura 42/38). Tüm bunlar göz önünde bulundurulduğunda iktidarın kaynağına ilişkin -bize oldukça aşina gelecek- bir resim çıktığ 1 görülmektedir.

\section{Emeviler ve Okültist Din Yorumu}

Tarih 632'yi gösterdiğinde emr-i hak vaki olur; Hz. Peygamber de ebedi âleme göçer. Ne var ki Hz. Peygamberin ardından Müslümanlar çok da iyi bir sınav veremezler. Daha ilk günden başlayan "kabile" esaslı tartışmalar (bkz. Cevdet Paşa, t.y.: I/196) derinleşir, ilk ilki halifenin ardından sıcak çatışmalara dönüşen hoşnutsuzluklar neticesinde, $\mathrm{Hz}$. Ali'nin hilafetini tanımayan, en nihayetinde iktidarı zorla ele geçiren Emeviler ile birlikte hilafet resmen saltanata dönüşür. Olayların izahına ilişkin insani düzlem yerine "doğaüstü işaretlere, telmihlere" dayalı okültist argümanlar üzerinden yeni bir "teolojik" inşa süreci başlar. Buna göre Muaviye iktidarı ele geçirmiş olmasının "Allah'ın isteği ve yardımı" (bkz. es-Seyyid, 1985: 96). ile gerçekleştiğini" iddia eder. Toplumsal mekanizmaları bypass ederek kendisinin (doğrudan) Allah'ın halifesi (خليفة الله) olduğunu (Belâzurî, 1996: V/27) ileri süren Muaviye için ilk defa, "Sultan yeryüzünde Allah'ın gölgesidir" (السلطان ظل الله في الأني (الارض tabiri kullanılır (Belâzurî, VII/111). Böylece Hz. Peygamber döneminin, devlet idaresinin toplumsal bir süreç şeklindeki dizaynı yıkılarak yeniden gizil / okültist bir el yordamıyla "seçilmişlik" öğretisine dönülür. Hz. Peygamber' in vefatından sadece 30 yıl kadar sonra yaşanan o iç savaşlardan Hz. Hüseyin'in katlinde (680) tüm bu "şer" olayların bir "yazgı" neticesi gerçekleştiği ileri sürülerek insani sorumluluk buharlaştırılır. Olup bitenleri Allah'ın ezelden "yazdırdığı" (konuştuğu: mütekellim) üzerinden "şer" Allah'a nispet edilerek Cahiliye düalizminin dehr kültü de geri dönmüş olur: "Dehre sövmeyiniz çünkü dehr Allah'tır.” (Müslim, 1991: I/1763).

$\mathrm{Bu}$ iddialara karşı itirazlarla tartışma dallanıp budaklanır; olup bitenler bir kenar bırakılıp "kadim yazgının imkânı" üzerinden yazgının Arapçanın kıdemi konusuna gelinir (Suyûtî, 2011: 7/365). Allah'a Arapça nispet edilemeyeceğini, dilin "insan icadı" olduğunu savunan Mu'tezile'ye göre Allah'a bir "ses" de nispet edilemez. Ses en nihayetinde havada bir titreşim olup "konuşma" anlamında ise tıpkı insandaki gibi bir organ (ağız) ve buna bağlı olarak sınırları belli (bir yerde bulunup aynı anda başka bir yerde olmamak) bir "beden” gerektirir. Bu itirazlara karş1 Allah'ın bulunduğu yerin "arş" olduğu ve buna göre bulunmadığı yerler olduğu, diğer şeyler gibi bir "şey" olduğu, ondan "ses" sadır olmasının da yadırganamayacağı ileri sürülür (İbn Hanbel, 2003: 137). "Ses" (konuşma) üzerinden Allah'1 bu şekilde somutlaştırma konusundaki 1srar, her dilde olduğu gibi Arapçada da olan ve Kur'an'a da yansıyan Allah'a ilişkin kimi deyim ifadelere yöneltir. Böylece, “Allah'1n eli - يد الله (el-Maide, 5/64), "Rahman arşa istiva etti” (et-Taha, 20/5) ( الرحمن على العرش استوى) gibi ifadelerden Allah'1n -şekli belirsiz- ama "el”, "göz" vb. olarak organlarının olduğu ileri sürülür. Bunun Allah'1 cisimleştirmek (İbn Hanbel, 144), Allah'1 yaratılmış varlıklar gibi görmek anlamına geleceği itirazına ise Allah'ın zaten diğer şeyler gibi bir "şey" olduğu, aksini iddia etmenin, dolaylı yoldan (ta'til) Allah'ı inkâr etmek anlamına geleceği ileri sürülür. Bunun için dilbilgisi bakımından bile zorlama yorumlara gidilir. Arapça açısından örneğin "Allah'ın eli" (يد الله tabiri açıkça bir isim tamlaması (izafet) olduğu ve el denince de insan zihninde ne anlaşılması gerektiği açık olduğu halde "el" (يد) için "sıfat" denerek Allah hakkındaki deyim ifadeler "haberi sıfatlar" şeklinde kategorize edilir. Aynı şekilde “istiva” sözcüğü açıkça isimdir (mastar) ve Allah'a nispet edildiğinde de yine bir isim tamlaması olduğu halde yine sıfat denir. Böylece zatî ve subutî sıfatların yanı sıra bir de haberi sıfatlar kategorisi oluşturulmuş olur. Sonuç olarak erken dönemde Kerbela ve diğer feci olayları kadim "yazgı" ile izah etme ve sorumluları kurtarma çabası nihayetinde Allah'a bir "mekân" isnadına varır ve burası "dünya merkezli" evren fikrine uygun olarak yedinci kat semadir.

\section{Müslümanlar ve Gök Bilimine Katkıları}

Muhtemelen yaşanan teolojik tartışmaların da bir uzantısı olarak Abbasiler döneminde Müslüman bilginler (Avrupa'dan çok daha önce) astronomi konusunda önemli çalışmalar yapmıştır. $\mathrm{Bu}$ dönemde öne çıkan Mu'tezili bilginlerin, dünyanın şekli ve hareketini de tartıştıkları, hareket etmeyen bir dünya ve geosantrik bir evren fikrinin baskın olduğu görülmektedir (bkz. Yıldız, 2020: 215-224). Ancak bir yandan da bu sürece deneysel çalışmalar eşlik eder. İslam dünyasında ilk rasathane olan Şemmasiye Rasathanesi, Abbasi Halifesi Me'mun dönemine (813-833) rastlar (Bayrakdar, 2000: 98). Bağdat'ta kurulan ve Yahya b. Mansur'un (ö. 830) rehberliğinde faaliyet gösteren rasathanede pek çok astronom çalışmış olmakla birlikte özellikle Muhammed b. Musa el-Hârizmî (ö. 847) ve Sind b. Ali (ö. 864) gibi bilginlerin adı geçer. Şemmâsiye'nin kuruluşundan sonra yine Halife Me'mun, Şam'ın kuzeyinde yer alan Kâsiyûn dağı üzerindeki Deyrimurrân Manastırı'nda ikinci bir rasathane kurdurur. (Bakkal, 2019: 
108). Kuruluş yerine nispetle buna Kasiyun Rasathanesi adı verilir. Amaç Şemmâsiye'de elde edilen verilerin sağlamasını yapmaktır. Burada beş metre yüksekliğinde bir güneş saati ile iç yarıçapı beş metre olan bir mermer duvar kadranı bulunmaktadır.

Yahya b. Mansur buralarda yapılan çalışmaların sonuçlarını ez Zicü'l Mümtehan adıyla kitaplaştırır (bkz. Unat, 2013: XLIV/401). Kitapta yer alan astronomi cetvelleri yüzyıllarca elden ele dolaşır. $\mathrm{Bu}$ rasathanelerde yapılan çalışmaların niteliği Avrupa'da ancak 15. yy.da görülecektir. Ne var ki tüm bu çalışmaların daha çok Mu'tezile'den gelmesi ve 10 . yy.da oluşan siyasi dengelerin Ehl-i Eser lehine şekillenmesi sonucu süreç, Kur'an'da mecaz olduğunu savunan deney ve gözlem metoduna açık Mu'tezile'nin tasfiyesi yönünde gelişir. Böylece ana akım arasında rivayet kültürünün yanı sıra Allah'ın maddi âlemdeki ayetlerini okumaya dayalı çalışmayı önemseyen bir ekol de kalmaz. Hatta doğaya ve doğa yasalarına yönelenler "Tabiatçılar" şeklinde kategorize edilerek mahkûm edilir (Gazzâlî, 2003: 6).

\section{Dünya Merkezlilik Vurgusu ve Âlimlerin Açmazı}

Mu'tezile'nin tasfiyesiyle "ilmi”" çalışmalar tümüyle "dilsel” bir faaliyet halini alırken (bkz. A. el-Bağdâdî, 2016: 149) sorunlar tevil yoluyla (تأويل اليد المضافة إلى الله) (A. el-Bağdâdî, 142) çözülmüş olur. Ancak bir yandan da Allah hakkındaki "tecsim" ifadelerin kabulü de kolay olmadığından özellikle Eş'ari bilginler (halef), kökleri daha önce İbn Küllab (ö. 854), İmam Buhari (ö. 869) ve Mâturîdî (ö. 944) gibi bilginlere giden bir ayrımla "Allah'ın konuşması" (Kelamullah) yeniden tarif edilir. Buna göre Kur'an'ın nüzulünden önceki hali "kadim" olup "Kelâm-1 Nefsi”" denir. Hz. Peygamber'e gelmiş ve onun tarafından ifade edilmiş telaffuzu ise "mahlûk" (Arapça) olup "Kelâm-1 Lafzi" denir (Eş'arî, 1990: II/257). Bu çıkış karşısında Ehl-i Eser'in, diğer âlimlere olduğu gibi Eş'arîler'e karşı da şiddeti kimi zaman büyük toplumsal olayların yaşanmasına neden olsa da sıfatlar konusundaki ayrışma bir yandan da Eş'arîlik ile Mâverâünnehir bölgesinden gelen Mâturîdîlik arasında bir yakınlaşmayı getirir. Böylece bu iki yorum resmi olarak hâkim hale gelir. Ancak düşünsel faaliyet artık dış dünyaya ilişkin deney ve gözlem yerine tümüyle dil kaidelerine dayalı çıkarsamalara kaymıştır. Bu nedenle Ehl-i Eser ile araya belli bir mesafe konmuşsa da bu yöntemsel bir farklılaşmadan çok siyasi saiklerle gerçekleşmiş olup dilsel çözümlerden (tevil) ibarettir. Oysa dilin kültürel doğası gereği dış dünyaya ilişkin yorumlar savrulmaya son derece açıktır. Dış dünyanın dile yansıması en nihayetinde insanoğlunun bilinçli, metodik deney ve gözlemlerinin değil, hayat içinde gerçekleşmiş deneyimlemelerinin analojik ifadesi olarak görülebilir. Böylesi bir yöntemin, klasik metinlerde görüldüğü üzere aslında Ehl-i Eser öğretinin mantıksal sonucu olan dünya merkezli evren algısını daha bir pekiştirdiği anlaşılmaktadır. Evrenin merkezi konumundaki dünyanın sabit olduğu fikrini savunan Fahreddin Râzî (ö. 1210) Bakara Suresi 22. ayet ile ilgili şöyle demektedir:

Yer şayet hareketli olsaydı, bu hareket ya dikey (düşme) olurdu veya dairevi olurdu. Eğer dikey olsaydı, mutlak manada o yeryüzü bizim için bir döşek olmazdı. Çünkü bu durumda yüksekten atlayan bir kimse yeryüzü de aynı zamanda düşme halinde (هاوية) olduğundan yere ulaşamazdı. Arz, insandan daha ağırdır ve düşüş halinde olan iki şeyden ağır olan, hafif olandan daha hızlıdır ve yavaş olan ağır olana yetişemez. Bu durumda insanın yeryüzüne ulaşması mümkün olmazdı (Râzî, II/102).

Râzî, devamında benzer bir mantıkla dünyanın dairevi olarak da hareket etmediğini ispatlamaya çalışır. Müslümanlarla ve Ehl-i Kitap'ın, “dünyanın sabit olduğu” konusunda ittifak ettiğini aktarın Kurtubî (ö. 1273) ise Ra'd Suresi 3. ayeti, "dünyanın şeklinin kürevi olduğunun iddia edenlerin

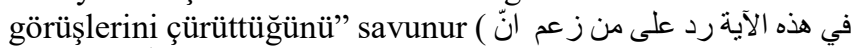
(الأرض كالكرة (Kurtubî, 2006: XII/8). Kurtubî, Kur'an'daki "Arş" sözcüğü (el-Hakka, 69/17) ile ilgili de şu rivayeti aktarır:

Arş1 dört melek hamletmişlerdir. Bu meleklerden birisi insan suretindedir. Birisi de sevr (öküz) suretindedir. Bir diğeri kartal suretindedir ve diğeri ise aslan suretindedir (Kurtubî, XXI/202).

İslam dünyasında deney ve gözleme dayalı ilmi çalışma girişimleri özellikle astronomi sahasında daha sonraki yüzyıllarda da olmuştur. Bu girişimlerden biri 15. yy.da kendisi de aynı zamanda bir astronom olan Timur İmparatorluğu hükümdarı Uluğ Bey’den (ö. 1449) gelir (Unat, 2012: XLII/127). Uluğ Bey, Semerkant'ta inşa ettirdiği rasathaneye Kadızâde Rumî, Gıyaseddin Cemşid, Ali Kuşçu gibi dönemin önemli bilginlerini davet ederek kendisinin de katıldığı çalışmalar yapılır. Ne var ki, dini değerleri örtülü bir siyasi nüfuz temini için kullanmak isteyen tutucu çevrelerle Uluğ Bey arasında siyasi anlaşmazlık yaşanır. Uluğ Bey’in astronomi çalışmalarını insanları ve hatta oğlunu ona karşı kışkırtmak için hedef haline getiren bu çevreler babası ile sorun yaşayan oğlu Abdullatif Mirza'yı, Uluğ Bey'e karşı isyana sevk ederler (bkz. Çağlar, 2015: 95). Oğlunun kendisine karşı bu kadar düşman kesileceğine ihtimal vermeyen Uluğ Bey, 1448'de yaşanan savaşta yenilir, tahttan indirilir ve ardından öldürtülür. Uluğ Bey’in öldürülmesinden sonra oğlu Abdullatif Mirza'dan kaçan Ali Kuşçu (ö. 1474) İstanbul'a gelir (Fatih dönemi) ve müderris tayin edilir (bkz. Togan, 1946: I/376).

Bir başka rasathane girişimi 16. yy.da Osmanlı'da görülür. Avrupa'da Tycho Brahe ile hemen hemen aynı tarihlerde, Mehmet Takiyyüddin (ö. 1585) Padişah III. Murat'1 (1574 1595) ikna edip ödenek alarak İstanbul Tophane sırtlarında Osmanlı'nın ilk rasathanesini kurar. Mehmet Takiyyüddin burada gökbilim ile ilgili önemli çalışmalar gerçekleştirir. Ancak 1577 'de görülen bir kuyruklu y1ldız ve ardından 1578 'de ortaya çıkan veba halk arasında rasathane ile ilgili dedi-kokulara neden olur. Rasathanedekilerin "meleklerin bacaklarına baktıkları, kuyruklu yıldızın buna karşı bir ihtar olduğu ve ardından salgın baş gösterdiği" şeklinde söylentiler yayılır. Dedikodular artınca şeyhülislam da rasathaneye ilişkin olumsuz kanaatlerini padişaha bildirir ve nihayetinde rasathane topa tutularak y1k1lır (Akgül, 40). Rasathanenin yıkılış nedeni hala tartışılsa da o zamanlar hemen her yerde hâkim olan dünya merkezli evren fikri ve hayata ilişkin bütün kabullerin buna göre şekillendiği düşünüldüğünde konunun ne kadar hassas ve istismara açık bir alan olduğu anlaşılabilir. Bugünden bakıldığında anlaşılması güç görünse de aslında o çağlarda tüm bir toplumsal bilinçaltı ve hatta siyasi sistem bu kabuller üzere kuruludur. Bunun en açık ifadelerinden birini İstanbul'da, Topkapı Sarayı Saltanat Kapısı (Bâb-1 Hümâyûn) üzerinde görmek mümkündür. Kapı üzerinki Arapça kitabede şöyle denmektedir: 


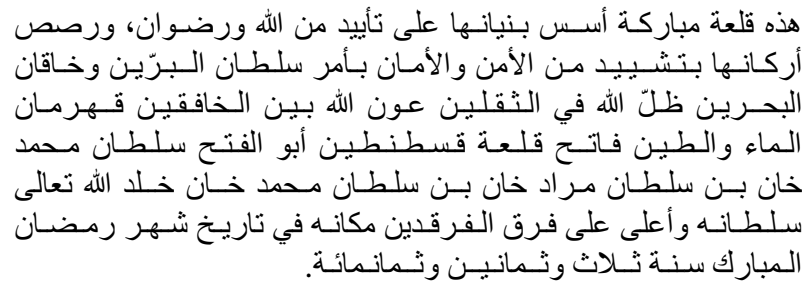

Bu mübarek bir kaledir ki Allah'ın te'yid ve rızasıyla kuruldu ve erkânı emn-ü emânıyla kuvvet buldu. Karaların sultanı denizlerin hakanı, iki âlemde (sakaleyn) Allah'ın gölgesi, doğuda ve batıda Allah'ın yardımı, denizlerin ve karaların kahramanı, Kostantin Kalesi'nin fatihi Sultan Mehmed Han oğlu Sultan Murad Han oğlu Ebu'l-Feth Sultan Mehmed Han'ın Allah-u Teâlâ saltanatını daim eylesin ve mevkiini kuzey yıldızlarının fevkinde etsin. Sekiz yüz seksen üç senesi Ramazanü'lMübarek ayında inşa edildi (Ayverdi, 1974: IV/700).

Kitabede konumuz açısından dikkat çeken "iki âlemde Allah'ın gölgesi" ( ظلّ الله في الثقلـنـ) ifadesinde "iki âlem" yani "sakaleyn" ile bilindiği üzere "insanlar ve cinler alemi" kast edilmektedir. Buna göre padişah sadece insanların değil, cinlerin de hükümdarı olmak durumundadır (Öz, 2009: XXXVI/325). "Zillullah" tabiri ise siyasi meşruiyetin gökselliğine ilişkin kadim kabullerin İslam dünyasındaki iz düşümüdür. Tüm bunlar dünya merkezli evren fikrinin kültürel/teolojik bilinçaltında aslında ne kadar güçlü temellerinin olduğu açıça göstermektedir. Öyle ki Kopernik'ten yüzlerce y1l sonra yazılan tefsirlerde "Güneşin deveranı (dönmesi) sayesinde fusûli erbaa (dört mevsim) husûle gelir (meydana gelir), kamerin devranı sayesinde de ayların ittidası (sayısı) ve nihayeti anlaşılır" (Bilmen, 1964: IV/1696) şeklinde yazılabilmektedir.

\section{Sonuç}

Müslümanların Batı karşısında neden geri kaldıkları sorgulanırken konu genellikle dönemin verili siyasal durumlarından bağımsız olarak sıklıkla sebep doğrudan din olarak gösterilir. Oysa dinin yorumları da toplumların siyasi ve sosyal süreçlerinden bağımsız değildir. Tarihsel gerçekler göstermektedir ki, Müslüman bilginler pek çok sahada aslında Batılılardan önde bile gitmişlerdir. Ne var ki, tarihin akışına hakikat peşindeki bilginlerin gayretlerinden çok siyasal dengeler yön verir. Kendisine meşruiyet arayan siyasi hesaplar da kaçınılmaz olarak dini düşünceyle birlikte dış dünya algısına uzanan teolojik ön kabullere yol açar. Hz. Peygamber sonrası yaşanan ihtilaflar Emeviler döneminde siyasi meşruiyeti, Hz. Peygamber'in bıraktığ 1 gibi insani bir süreç ve "şura" yerine yeniden okültist inanışlarda aramaya varır. Dinin hâkim yorumunu da belirleyen bu siyasi müdahale, deney ve gözleme dayalı bilgiyle çelişik bir teolojik üretime yol açar. Bunun için de zahmetli bilimsel çalışma metodu yerine, kolayca şekil verilebilen dilin soyut - zahmetsiz zemini tercih edilir. Kelimelerin, ufkun ötesinde, zamanın bahrinde kaybolan kökleriyle anlam silsilesi, sebep sonuç ilişkisi de kopar, geriye dil fanusuna sıkışmış bir teoloji kalır. Oysa dil özünde insan icadı olup onun da bir tarihi vardır. Ezberlerinin bozulacağı korkusuyla teleskoptan bakmaya cesareti olmayanlar kelimelerin ardına saklanır. Kelimeler, iç bünyede belki kitleleri konsolide etmek için işlevsel olabilir. Ancak Shakespeare'den "Şeyh Pir" çıkararak dış dünyayı dizayn etmek mümkün değildir.

\section{Kaynakça}

Ağaoğulları, M. A. (2020). Sokrates'ten Jakobenlere Batı'da Siyasal Düşünceler. İstanbul: İletişim Yayınları.

Akçura, Y. (2016). Şark Meselesine Dair. İstnabul: Ötüken Yayınlar1.

Akgül, U. (1997). Osmanlının Uzaya Bakan Gözü Takiyüddin ve İstanbul Rasathanesi. Bilim ve Teknik, 351, 34-42.

Ayverdi, E. H. (1974). Osmanl Mimarisinde Fatih Devri. Cilt IV. İstanbul: Baha Matbaası.

Bağdâdî, E. (2009). Kitâbü'l-Muhabber. Beyrut: Dâru'lÂfâki'l-Cedîde.

Bağdâdî. A. (2016). Ehl-i Sünnet Akaidi. (Ö. Aydın, Çev.) İstanbul: İşaret Yayınları.

Bakkal, A. (2019) İslâm Tarihinde Rasathaneler. Bilimname, 39, 105-140.

Bastian, A. (1860). Der Mensch in der Geschichte: Zur Begründung Einer Psychologischen Weltanschauung. Cilt II. Leibzig: Verlag von Otto Wigand.

Bayrakdar, M. (2000). Íslâm'da Bilim ve Teknoloji Tarihi. Ankara: TDV Yayınları.

Belâzurî. (1996). Ensâbu'l Eşraf. Cilt VII. Beyrut: Daru'l Fikr.

Bilmen, Ö. N. (1964). Kur'an'ı Kerim'in Türkçe Meâl-i âlisi ve Tefsiri. Cilt IV. İstanbul: Bilmen Yayınevi.

Cevdet Paşa, A. (tarihi yok) Peygamberler ve Halifeler Tarihi. Cilt I. İstanbul: Merve Yayınları.

Ciavuk, M. A. (1977). el-Hayatu ve'l-Mevtu fi'ş-Şi'ri'l Câhiliyyi. Bağdat: Vizâratu'l Âlâm.

Cohen, H. F. (1994) The Scientific Revolution: A Historiographical Inquiry. Chicago: UOCP.

Çağlar, A. İhsan (2015). 15. Yüzy1l Mâverâünnehr'inde Nakşîliğin Sosyo-Ekonomik Yapısı: Hâce Ahrar ve Dönemi (1450-1490). Doktora Tezi, Hacettepe Üniversitesi Sosyal Bilimler Enstitüsü, Ankara.

Dönmez, İ. K. (2007). Örf. TDV İslam Ansiklopedisi içinde (Cilt. XXXIV, s. 93-94). İstanbul: TDV Yayınları.

el-Mahallî, C. ve es-Süyûtî, C. (1971). Tefsîru'l-Celâleyn. Beyrut: Daru'l-Kutubu'l-İlmiyye.

Eş’arî. (1990). Maḳalatu'l-İslâmiyyîn. Cilt II. Beyrut: elMektebetï'l-Asriyye.

Gazzâlî, M. (2003). el-Munkız mine'd-Dalâl. İskenderiyye: Dâru'l-Endelus.

Gera, D. L. (2003). Ancient Greek Ideas on Speech. Language and Civilization. Norfolk: Oxford University Press.

İbn Hanbel, A. (2003). er-Red ale'l-Cehmiyye ve'zZenâdıka. Riyad: Dâru's Sebât.

İbn Hişam. (1990). es-Siretü'n-Nebeviyye. Cilt II. Beyrut: Darü'l Kitabil Arabi.

İbn Kesîr. (1999). Tefsiru'l-Kur'an'il-Azîm. Cilt VII. Riyad: Dâru't-Tayyibe. 
İbnü'l-Kelbî. (1995). Kitâbü'l Esnâm. Kahire: Dâru'lKütübi'l-Misriyye.

İpşirli, M. ve Çelebi, İ. (1997). Hasan Fehmi Efendi. TDV İslam Ansiklopedisi içinde (Cilt. XVI, s. 320-322). İstanbul: TDV Yayınları.

Kuhn, T. (1995). Bilimsel Devrimlerin Yapısı. (N. Kuyaş, Çev.) İstanbul: Alan Yayınları.

Kurtubî. (2006). el-Cami'u fî Ahkâmi'l-Kur'ân. Lübnan: Müiessesetü'r Risâle.

Müslim. (1991). Sahih. Cilt I. Beyrut: Dârü'l-Kutubi'lİlmiyye.

Ortaylı, İ. (2007). Türkiye Teşkilât ve İdare Tarihi. İstanbul: Cedit Neşriyat.

Öz, M. (2009). Sakaleyn. TDV İslâm Ansiklopedisi içinde (Cilt. XXXVI, s. 325-326). İstanbul: TDV Yayınları.

Râfiî. (1997). el-aziz Şerhü'l Veciz. Beyrut: Darü'l Kütübi'lİlmiyye.

Râzî, F. (1938). et-Tefsîru'l-Kebîr. Cilt II. Kahire: Müiessesetu'l-Matbuati'l-İslâmiyye.

Seyyid, M. S. (1985). Amr b. Ubeyd ve Ârâuhu el-Kelamiyye. Kahire: Mektebetu Nahdati'ş-Şark.

Sultanefendi, H. (2002). Osmanlı Hanedanı Saray Notları 1808-1908. Cilt I. İstanbul: Tekin Yayınları.
Suyûtî. (2011). ed-Dürrü'l Mensur fi't-Tefsiri'l-Me'sur. Cilt VII. Beyrut: Darü'l-Fikr.

Tassoul, J. L. ve Tassoul, M. (2004). A Concise History of Solar and Stellar Physics. Princeton: Princeton University Press.

Togan, Z. V. (1946). Umumi Türk Tarihine Giriş. Cilt I. İstanbul: Hak Kitabevi.

Toynbee, A. J. (1987). A Study of History - Abridgement of Volumes I-VI. Oxford: Oxford University Press.

Unat, Y. (2012). Uluğ Bey. TDV İslam Ansiklopedisi içinde (Cilt. XLII, s. 127-129). İstanbul: TDV Yayınları.

Unat, Y. (2013). ez-Zîcü'l-Mümtehan. TDV İslâm Ansiklopedisi içinde (Cilt. XLIV, s. 401- 402). İstanbul: TDV Yayınları.

Vural, Suat (2006). Hindistan'da İngiliz Yönetimi. Doktora Tezi, İnönü Üniversitesi Sosyal Bilimler Enstitüsü, Malatya 2006.

Yildız, M. (2020). Kelam Kozmolojisi, Mu'tezile'nin Âlem Anlayışı. İstanbul: Endülüs Yayınları.

Zemahşerî. (1998). Keşşaf. Cilt I. Riyad: Mektebetü'l Abikân.

Zeydan, C. (2013). Târîhu Temeddunu'l-İslâmî. Cilt III. Kahire: Hindawi. 


\section{Extended Abstract}

As reflected in the classical literature, the picture of the universe in the Qur'an is actually not different from the Earth-centered idea of the universe, which was accepted all over the world from Antiquity to the Middle Ages. Since the Quran does not claim to be a science book, this is not surprising. The main purpose of the Quran is to remind the principles of creation for the purpose of establishing a social order in which people can live together without subversion of the earth and shedding blood, regardless of the cultural level. However, while doing this, it is a logical necessity to act on the basis of the linguistic and cultural realities of the period. According to this, Islam has taken into account the perception of the universe of the society in which it was born (and the period), but has made fundamental changes here. Even understanding the essence of the Quran and the social change carried out by the Prophet, depends on understanding the philosophical, political and social reality of the preIslamic Arab society. At the time of the emergence of Islam, the Arabian peninsula was under Sasanian influence militarily and economically. Also in terms of religious belief, the peninsula was under the influence of Majusism based on dualist cosmology. According to Majusism, the universe is the battleground of two forces " divine" (rahmani) and "evil" (şeytani; attributing divinity to the devil). According the Arabs of Jahiliyyah (paganism), the victory of Sassanids against Eastern Rome during the emergence of Islam, was success of dualism against the Trinity, which we can see as a corrupt interpretation of the tawheed (monotheism). At the dualist belief of the era of Jahiliyyah, the world of spirits is bipolar: on the one hand, "God" and angels obedient to him, on the other hand, "rebellious" demon -İblis- and other demonized "evil spirits". Between these two poles, a conflict is taking place and human beings are in a "caught in between" in this conflict environment. The Arabs of Jahiliyyah call it "Dahr", meaning "time".

In this dualistic universe, the Arabs seek ways to please both parties that affect their lives almost equally. For this, they try to approach God through the angels they claim to be the "daughters of God" by attributing "femininity". The sculptures erected around the Kaaba are actually the socalled "bodies" erected for angels, and it is believed that angels incarnate in these sculptures in order to establish contact with them (such as the soul-body relationship in humans). On the other side, they see deserted or abandoned places, dwellings of devils and build altars there for them. It is considered that the priests, who are believed to know some hidden information, actually got acquainted with it thanks to the "jinn" who stole this information from the "seventh heavenly floor" and brought it to them. Islam denies first and foremost, this dualistic cosmology of the Jahiliyyah. The gates of the heavens were closed with Islam, and the devils no longer had the opportunity to listen to the hidden information from the divine realm. Accordingly, the relationship between human and nature is redefined on a rational basis. The reasons for the evil (shar) that happen to people are not "evil spirits", but because people have committed their own hands; there is no "evil" in nature. This cosmology also has social and political consequences. First of all, with Muhammad (Hâtemü'n nübüvve), prophecy will end, the conversation (vahiy) of God with a human in this sense (theology) will come to an end and the human being will walk the path from now until doomsday on self (sociology). The first thing that Mohammed does after his migration to Yathrib, to bring together all the communities in the city on a common ground where they can live together with a "written document". A definition of "ummah (commune) is also seen in the document, which consists of very egalitarian and just principles. It is clear that this definition includes not only Muslims but also everyone who signed the document.

From that on, the city of Yathrib has acquired a "Madinah" character (Yathrib Medina). Madina, where affairs are carried out by "shura" (council), means a kind of "republic". Based on this practice of Muhammad, it can be said that ummah is a community that has adopted a certain geography, signed a written document, that reflects the ideal of living together, within the respect of each other's law and has the power to protect this document economically and militarily. So that although those who live in Madinah and sign this document are considered to be from the ummah, those who are Muslim and still have not migrated are excluded from the notion of ummah. Considering all these, the concept corresponds to the concept of nation today and in modern Arabic, the term ummah is used in the sense of "nation". As can be understood from the definition of ummah, the political philosophy of Islam requires individuals with extremely strong consciousness of existence. It is no accident that the image of a powerful individual is accompanied by an emphasis on "reason." Unlike the tribal order that indexes their behavior to the group they belong to, individuals are invited to make conscious choices. This strong emphasis of Islam on the individual is much more evident in the creation story of Adam, which describes the human philosophy of the Quran. Human, who represent God on earth, are also authorized for the social order. In the personality of Adam is the human species meant and accordingly, the adjective "the caliph of God" applies to all people. However Muslims after Muhammad, have cannot be very successful in power change. However, after Muhammad, Muslims were not very successful in power change. With the Umayyad dynasty who seized power by force, a new "theology" is built, based on the belief that the source of sovereignty comes from the god in the seventh heaven. 